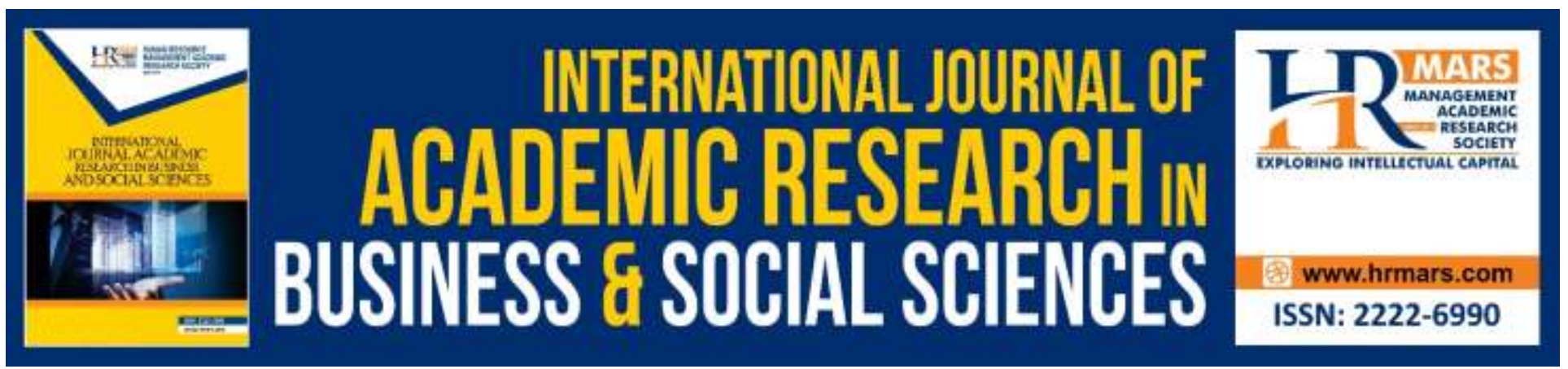

\title{
A Comparative Analysis of Inflation Dynamics Models in Nigeria
}

Ibrahim Shaibu, Ifuero Osad Osamwonyi

To Link this Article: http://dx.doi.org/10.6007/IJARBSS/v10-i2/6949 DOI:10.6007/IJARBSS/v10-i2/6949

Received: 20 January 2020, Revised: 01 February 2020, Accepted: 12 February 2020

Published Online: 29 February 2020

In-Text Citation: (Shaibu \& Osamwonyi, 2020)

To Cite this Article: Shaibu, I., \& Osamwonyi, I. O. (2020). A Comparative Analysis of Inflation Dynamics Models in Nigeria. International Journal of Academic Research in Business and Social Sciences, 10(2), 558-557.

Copyright: (C) 2020 The Author(s)

Published by Human Resource Management Academic Research Society (www.hrmars.com)

This article is published under the Creative Commons Attribution (CC BY 4.0) license. Anyone may reproduce, distribute, translate and create derivative works of this article (for both commercial and non-commercial purposes), subject to full attribution to the original publication and authors. The full terms of this license may be seen at: http://creativecommons.org/licences/by/4.0/legalcode

Vol. 10, No. 2, 2020, Pg. 558 - 577

http://hrmars.com/index.php/pages/detail/IJARBSS

JOURNAL HOMEPAGE

Full Terms \& Conditions of access and use can be found at http://hrmars.com/index.php/pages/detail/publication-ethics 


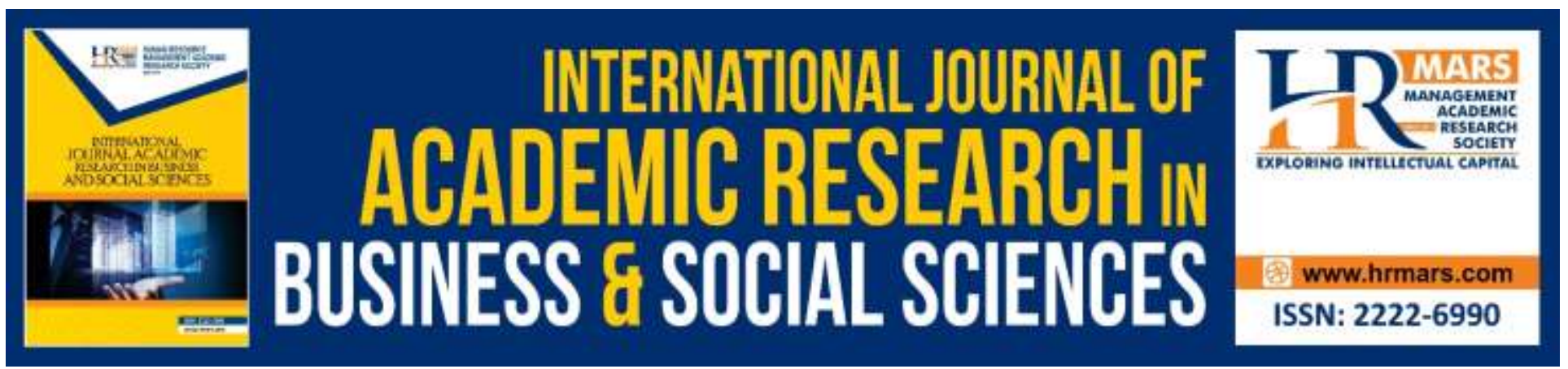

\title{
A Comparative Analysis of Inflation Dynamics Models in Nigeria
}

\author{
Ibrahim Shaibu, Ph.D. \\ Associate Professor, Department of Business Administration, University of Benin, Benin City \\ Email: ibb.shaibu2013@gmail.com
}

\author{
Ifuero Osad Osamwonyi, Ph.D. \\ Professor, Department of Banking and Finance, University of Benin, Benin City \\ Email: ifueroosad@yahoo.co.uk
}

\begin{abstract}
This study empirically developed a multivariate autoregressive distributed-lag (ARDL) model and a univariate autoregressive integrated moving average (ARIMA) model for inflation in Nigeria, ascertained the stability of the models, and compared the performance of the models. This study used quarterly time series data from 1988 to 2017. The data were sourced from the publications of the Central Bank of Nigeria (CBN) and the National Bureau of Statistics (NBS).The study applied the ordinary least squares (OLS) method with the aid of EViews software for estimation purposes. The study found that: (1) $\operatorname{ARDL}(4,2,2,1)$ and $\operatorname{ARIMA}(2,1,3)$ were the most appropriate models of inflation in Nigeria under model identification, identification, estimation, and diagnostic checking; (2) inflation in Nigeria was largely expectations-driven; and (3) inflation in Nigeria was influenced by the exchange rate, interest rate, and broad money supply (liquidity) both in the short-run and in the longrun.The study recommended that: (1) a "one-model-fits-all" for inflation rate dynamics in Nigeria should be discouraged and that different models should employed to complement one another; (2) regulatory authorities should ensure a high degree of transparency in monetary policy making and implementation; and (3) efforts should be made by the regulatory authorities to control money supply and ensure exchange rate and interest stability, in order to stem inflationary tendencies.
\end{abstract}

Keywords: Inflation Dynamics, ARDL, ARIMA, Expectations, EViews.

\section{Introduction}

Concern over inflation is a legitimate policy concern because persistence inflation is perhaps the second most serious macroeconomic problem confronting the world economy today-second only to hunger and poverty in the third World (Dwivedi, 2008). High inflation is detrimental to an economy because it distorts prices, depletes savings, discourages investment, fuels capital flight, 
hinders growth, and makes economic planning difficult. For these reasons, keeping inflation under control has been one of the most daunting tasks of monetary authorities of countries.

Achieving the objective of keeping inflation low and stable requires that its causes be identified and understood. The construction of scientific econometric models for inflation has become important in Nigeria because strategic decisions at all levels have been criticized for lack of analytical rigour and without the benefit of appropriate empirical framework (Adenikinju, Busari, \& Olofin, 2009). The result has been that decision-making at all levels tend to rely relied upon macroeconomic forecasts that may not be anchored on scientific models that track major economic indices. Scientific economic models will enable policy makers to exercise their judgemental analysis in a much more structured and quantified manner and to develop a more adequate understanding of macroeconomic time line.

Some researchers have investigated the nature and causes of inflation in Nigeria (such as Adenekan \& Nwanna, 2004; Asogu, 1991; Fakiyesi, 1996; Moser, 1995; Oyaromade, 2009; Rapu, Gaiya, Eborieme, Nkang, Audu, Golit, \& Okafor, 2016). A variety of ARIMA methods have been used for modelling time series in the literature. ARIMA methods have been used to model inflation (examples are Adebiyi, Adenuga, Abeng, Omamukue, \& Ononugo, 2010; Samad, Ali, \& Hossain, 2002; Stockton \& Glassman, 1987; Valle, 2002). ARIMA models have also been used to model exchange rates (such as Ajao, Obafemi, \& Bolarinwa, 2017; Chamalwa, Rann, \& Idris, 2016; Nwankwo, 2014; Nyoni, 2018; Olatunji \& Bello, 2015; Onasanya \& Adeniji, 2013). From the review of empirical literature review, we found that the static ordinary least squares (OLS) regression methods were largely employed in modeling inflation dynamics; no evidence that Box-Jenkins (ARIMA) methodology was properly applied to modelling inflation dynamics in Nigeria; and the forecast performances of the estimated models were not properly evaluated.

This paper also differed from the reviewed studies in the following:

a. dynamic models were used for empirical analyses;

b. the Box-Jenkins ARIMA procedure of model identification, selection, parameter estimation, diagnostics checking, and forecasting was strictly followed;

c. the forecast performance of the models was evaluated.

The concept of inflation dynamics has been extensively discussed in the literature. However, different dimensions witnessed in the various analyses have continued to create vacuum for further studies. A major concern can be raised on the modelling of inflation dynamics in Nigeria: Do multivariate models perform better than univariate models in the analyses of inflation dynamics? This study attempted to answer this question by developing the autoregressive distributed-lag (ARDL) and autoregressive integrated moving average (ARIMA) inflation models for inflation in Nigeria, ascertaining the stability of the models, and comparing the performance of the models.

\section{Review of Literature}

Economists generally agree that a long-sustained period of inflation is caused by a combination of cost factors, money supply, and decline in output (Barro \& Grilli, 1994; Olofin, 2001). The prevailing view in mainstream economics is that inflation is caused by the interaction of the supply of money with output and interest rates (Odedokun, 1993; Stiglitz \& Greenwald, 2003). Views of mainstream economics can be broadly divided into two camps: the "monetarists" who believe that monetary effects dominate all others in setting the rate of inflation (e.g. Friedman \& Kuttner, 1993; 
INTERNATIONAL JOURNAL OF ACADEMIC RESEARCH IN BUSINESS AND SOCIAL SCIENCES Vol. 10, No. 2, Feb, 2020, E-ISSN: 2222-6990 @ 2020 HRMARS

Friedman \& Schwartz, 1973), and the "Keynesians" who believe that the interaction of money, interest and output dominate other effects (e.g. Olivera, 1964; Sunkel, 1960). Controversy between these viewpoints has led to differing prescriptions about the appropriate policy response.

Since the mid-1970s, inflation has become a significant problem for Nigeria. A variety of models and empirical methods have been used in attempts to analyze inflation determinants. A study by Oyejide (1972) constitutes a pioneering attempt at providing explanation of the causes of inflation in Nigeria, most especially from the structuralism perspective. He examined the impact of deficit financing in propagating the inflation process in Nigeria and came to the conclusion that there was a strong relationship between inflation and the various measures of deficit financing that were in use between 1957 and 1970. Adeyeye and Fakiyesi (1980) tested the hypothesis that the rate of inflation in Nigeria is linearly related to the rate of growth of money stock, government expenditure, especially deficit, and growth of government revenue, especially monetization of foreign exchange from oil export. The result established some significant positive relationships between inflation rate and growth in bank credit, growth of money supply, and growth in government expenditure, while the relationship with growth of government revenue was uncertain.

Asogu (1991) investigated the nature and causes of inflation in Nigeria, using annual time series data from the period 1960 and 1989. Using the OLS regression technique, the results showed that real output, net exports, current money supply, domestic food prices and exchange rates were the major determinants of inflation in Nigeria. He concluded that fiscal and monetary tools together with growth in productivity may curtail inflationary pressures. Egwaikhide, Chete, and Falokun (1994) used time series econometric technique of co-integration and error correction mechanism (ECM) to analyze the impact of monetary expansion and exchange rate depreciation on inflation in Nigeria. The study showed that the Nigerian inflation was influenced by both monetary and structural factors; and that official and parallel market exchange rates exerted an upward pressure on the general price level. They recommended the use of a combination of policy measures to put inflation under effective control in Nigeria.

Moser (1995) assessed the main determinants of inflation in Nigeria using annual time-series data from 1960 to 1993 within the co-integration and error-correction modelling framework. The variables used were nominal broad money, exchange rate, interest rate, expected inflation, real income, and rainfall. His results showed that monetary expansion, driven mainly by expansionary fiscal policies, explain to a large extent the inflationary process in Nigeria. Fakiyesi (1996) investigated the major determinants of inflation in Nigeria, using annual data from 1960 to 1994 and ordinary least squares (OLS) econometric method to analyse the data. The independent variables used were growth in broad money supply, exchange rate, growth in real income, the level of rainfall, and the anticipated level of inflation. Using the autoregressive distributed-lag model, the empirical results suggested that the prime determinants of the inflation function were the growth in broad money, the rate of exchange, the growth of real income, the level of rainfall, and expected inflation. The paper concluded that continuous devaluation of the naira increased domestic prices and thus the need to limit the expansion of monetary growth and fiscal discipline.

Adenekan and Nwanna (2004) investigated inflation dynamics in Nigeria using annual data from 1959 to 2002. The series were consumer price index, money supply and exchange rate. Using the co-integration and error-correction modelling framework, they found that changes in the price level in the immediate past period was a major driver of inflation rate, suggesting a possibility of a 
INTERNATIONAL JOURNAL OF ACADEMIC RESEARCH IN BUSINESS AND SOCIAL SCIENCES Vol. 10, No. 2, Feb, 2020, E-ISSN: 2222-6990 @ 2020 HRMARS

self-generating inflationary process. However, money supply exerted a fairly significant influence on inflation, while the impact of exchange rate was not significant in the short-run. They concluded that the monetary authority should ensure monetary control in order to mitigate the problems of inflation and exchange rate depreciation.

Olubusoye and Oyaromade (2009) analyzed the main sources of inflation in Nigeria using the framework of error correction mechanism using annual time series from 1970 to 2003 . The empirical results suggested that the prime determinants of the inflation function are the growth in nominal money stock, expected inflation, nominal interest and exchange rates, real income, and foreign prices. However, the level of output and lagged money supply were not significant in explaining inflationary trends during the period. The study concluded that efforts geared toward stabilising the domestic price level would continuously be disrupted by volatility in the international price of crude oil; thus, the need for diversification of the economy. Rapu, Gaiya, Eborieme, Nkang, Audu, Golit, and Okafor (2016) explored the drivers of in inflation using quarterly data from 2000 to 2015. Using the error correction mechanism, they found that growth in money supply, exchange rate depreciation, oil price dynamics, and imports were the main drivers of inflation in Nigeria.

The autoregressive integrated moving average (ARIMA) methodology is not embedded within any underlying economic theory or structural relationship (Hanke \& Wichern, 2005; Roberts, 2006). Since the advantages of developing theoretical underpinnings of a particular equation before estimating them have been emphasized in regression theory, why would we advocate ARIMA? The answer is that the use of ARIMA is appropriate when little or nothing is known about the dependent variable being forecasted or when all that is needed is one or two-period forecast (Pindyck \& Rubinfeld, 1981; Hanke \& Wichern, 2005; Roberts, 2006). In these cases, ARIMA has the potential to provide short-term forecasts that are superior to more theoretically satisfying regression models.

A variety of ARIMA methods have been used for forecasting purposes in the literature. Stockton and Glassman (1987) used ARIMA methodology to model inflation in the United States. They concluded that ARIMA models were theoretically justified and can be surprisingly robust with respect to alternative (multivariate) modelling approach. Upon finding the results for the United States, they commented that it was somewhat distressing that a simple ARIMA model of inflation should turn in such a respectable forecast performance relative to the theoretically based specifications.

Samad, Ali, and Hossain (2002) applied the Box-Jenkins (ARIMA) methodology to forecast prices in Bangladesh. They concluded that the ARIMA forecasts were satisfactory during and beyond the estimation period and could be used for policy purposes as far as price forecasts of the commodities were concerned. Valle (2002) used ARIMA and VAR models to forecast inflation in Guatemala. The results showed that ARIMA produced good results and the forecasts behaved according to the underlying assumptions of each model. Katimon and Demun (2004) applied the ARIMA model to represent water use behavior at the Universiti Teknologi Malaysia (UTM) campus. Using autocorrelation function (ACF), partial autocorrelation function (PACF), and Akaike's Information Criterion (AIC), they concluded that ARIMA model provides a reasonable forecasting tool for campus water use.

El-Mefleh and Shotar (2008) applied the Box-Jenkins (ARIMA) methodology to the Qatari economic data. They concluded that ARIMA models were modestly successful in ex-post forecasting for most of the key Qatari economic variables. The forecasting inaccuracy increased the farther away the forecast was from the used data, which is consistent with the expectation of ARIMA models. 
INTERNATIONAL JOURNAL OF ACADEMIC RESEARCH IN BUSINESS AND SOCIAL SCIENCES

Vol. 10, No. 2, Feb, 2020, E-ISSN: 2222-6990 @ 2020 HRMARS

Adebiyi, Adenuga, Abeng, Omamukue, and Ononugo (2010) examined the different types of inflation forecasting models covering ARIMA, VAR, and VECM models. The empirical results from ARIMA showed that ARIMA models were modestly successful in explaining inflation dynamics in Nigeria.

\section{Methodology}

\section{Data, Sources, and Description}

This study employed quarterly data from 1988 to 2017, sourced from the Central Bank of Nigeria Statistics database. The variables included inflation, broad money supply, exchange rate, and interest rate. Inflation is the composite consumer price index (CPI) of the rural and urban price indexes. Broad Money (M2) is the sum of currency in the hands of the public plus all of the public's deposits in commercial banks. Exchange rate is the price of one nation's currency in terms of another nation's currency. It is calculated as an annual average based on monthly averages (local currency units relative to the U.S. dollar). Interest rate is the percent increase in purchasing power (i.e., in real goods and services) that borrowers pay back to lenders.

\section{The ARDL Model Specification}

This study is hinged on the neo-Keynesian theoretical exposition of inflation which states that the general price is determined by aggregate demand for and aggregate supply of goods and services and the variation in the aggregate price level is caused by the shift in the aggregate demand and aggregate supply curves (Blinder, 2002).

The study autoregressive distributed-lag (ARDL) model in this study is drawn from the work of Olubusoye and Oyoramade (2009). Specifically, the supply side is captured by the tradeable sector whereas the demand side is represented by the non-tradeable sectors. Applying an IS-LM framework to an open economy, the general price level $\left(P_{t}\right)$ is a weighted average of the prices of tradeable ( $P_{t}^{T}$ ) and non-tradeable ( $P_{t}^{N T}$ ) goods with $\alpha$ representing the share of tradable goods in the total expenditure.

The price index is:

$$
P_{t}=E_{t}\left(P_{t}^{T}\right)^{\alpha}\left(P_{t}^{N T}\right)^{1-\alpha} \quad 0<\alpha<1
$$

$E_{t}$ is the nominal exchange rate. We can rewrite equation (1) as:

$$
P_{t}=E_{t} \frac{\left(P_{t}^{T}\right)^{\alpha}}{\left(P_{t}^{N T}\right)^{\alpha}} P_{t}^{N T}=e_{t}^{\alpha} P_{t}^{N T}
$$

where $e_{t}^{\alpha}=E_{t} \frac{\left(P_{t}^{T}\right)^{\alpha}}{\left(P_{t}^{N T}\right)^{\alpha}}$ and $e_{t}$ is the real exchange rate.

Now,

$$
P_{t}^{N T}=\left(P_{t}^{N T F}\right)^{\beta}\left(P_{t}^{N T O}\right)^{1-\beta}
$$

where superscripts NTF and NTO mean "nontraded food" and nontraded other" goods respectively.

Expressing equation (3) in natural logarithm form and using low case letters to denote logs, we have

$$
p_{t}^{N T}=\beta\left(p_{t}^{N T F}\right)+(1-\beta)\left(p_{t}^{N T O}\right)
$$

Substituting equation (5) into equation (6) gives 
INTERNATIONAL JOURNAL OF ACADEMIC RESEARCH IN BUSINESS AND SOCIAL SCIENCES Vol. 10, No. 2, Feb, 2020, E-ISSN: 2222-6990 @ 2020 HRMARS

$$
P_{t}=e_{t}^{\alpha}\left(P_{t}^{N T F}\right)^{\beta}\left(P_{t}^{N T O}\right)^{1-\beta}
$$

have

Expressing (5) in natural logarithm form and using low case letters to denote logs, again we

$$
p_{t}=\alpha e_{t}+\beta\left(p_{t}^{N T F}\right)+(1-\beta) p_{t}^{N T O}
$$

where $\beta\left(p_{t}^{N T F}\right)+(1-\beta) p_{t}^{N T O}=p_{t}^{N T}$

Assuming that demand for non-tradable follow aggregate demand in the economy, the price of non-tradable is determined by the equilibrium in the money market:

$$
\text { At equilibrium } \left.\frac{M_{t}^{s}}{P_{t}}=M_{t}^{D} \text {, [i.e. }\left(m_{t}^{s}-p_{t}\right)=m_{t}^{d}\right] \text { or } p_{t}=m_{t}^{s}-m_{t}^{d}
$$

where $\left(m_{t}^{s}-p_{t}\right)$ (by logging) is the real money supply and $m_{t}^{d}$ is the real money demand. $\mathrm{m}_{\mathrm{t}}$ represents broad money, and $p_{t}$, the price level measured by the CPI. $M^{S}$ represents the nominal stock of money.

Equating (5) and (6) and solving for $p_{t}^{N T O}$ yields

$$
p_{t}^{N T O}=\Phi\left[m_{t}-m_{t}^{d}-\alpha e-\beta p_{t}^{N T F}\right]
$$

where $\Phi=(1-\beta)^{-1}$

The demand for real money balances is assumed to be determined by the level of real income $\left(y_{t}\right)$, inflation expectation $\left(p_{r}^{e}\right)$, and the opportunity cost of holding money vis-a-vis other assets (real or financial), $\left(i_{t}\right)$.

$$
m_{t}^{d}=f\left(y_{t}, p_{t}^{e}, i_{t}\right)
$$

where $y_{t}$ is real income, $p_{t}^{e}$ is the expected rate of inflation and $i_{t}$ is the interest rate. Writing equation (9) explicitly, we have:

$$
m_{t}^{d}=\tau_{1} y_{t}-\tau_{2} p_{t}^{e}-\tau_{3} i_{t}
$$

Substituting equation (8) into equation (10) we have:

$$
p_{t}^{N T O}=\Phi\left[m_{t}-\tau_{1} y_{t}+\tau_{2} p_{t}^{e}+\tau_{3} i_{t}-\alpha e_{t}-\beta p_{t}^{N T F}\right]
$$

Again, substituting equation (9) into (7), we have:

$$
\begin{gathered}
p_{t}^{N T}=\beta p_{t}^{N T F}+(1-\beta)\left[\alpha_{1} m_{t}-\alpha_{2} y_{t}+\alpha_{3} p_{t}^{e}+\alpha_{4} i_{t}+\alpha_{5} e_{t}-\beta p_{t}^{N T F}\right](1-\beta)^{-1} \\
p_{t}^{N T}=\alpha_{1} m_{t}-\alpha_{2} y_{t}+\alpha_{3} p_{t}^{e}+\alpha_{4} i_{t}+\alpha_{5} e_{t}
\end{gathered}
$$

This removes the possibility of regressing food prices (a component of CPI) on CPI.

From (6) $p_{t}=\alpha e_{t}+p_{t}^{N T}$

where $p_{t}^{N T}=\beta\left(p_{t}^{N T F}\right)+(1-\beta)\left(p_{t}^{N T O}\right)$

Substituting for $p_{t}^{N T}$ in equation (13) using the expressing in (12) yields

$$
p_{t}=\alpha_{1} m_{t}^{s}+\alpha_{2} y_{t}+\alpha_{3} p_{t}^{e}+\alpha_{4} i_{t}+\alpha_{5} e_{t}
$$

Considering the possible linkage of international oil prices with the domestic price level, equation (14) is augmented with international oil prices in domestic currency, say $d$ to obtain

$$
p_{t}=\alpha_{0}+\alpha_{1} m_{t}^{s}+\alpha_{2} y_{t}+\alpha_{3} p_{t}^{e}+\alpha_{4} i_{t}+\alpha_{5} e_{t}+\alpha_{6} d_{t}+u_{t}
$$

where $\alpha_{0}$ is a constant and $u_{t}$ is a well behaved error term. 
INTERNATIONAL JOURNAL OF ACADEMIC RESEARCH IN BUSINESS AND SOCIAL SCIENCES Vol. 10, No. 2, Feb, 2020, E-ISSN: 2222-6990 @ 2020 HRMARS

Taking into account the special characteristics of the Nigerian economy and by considering recent empirical studies in the context of inflation, an empirical multivariate functional relationship between the selected monetary variables and inflation is constructed which emphasizes the effect of expected inflation, exchange rate, interest rate, and broad money supply on current inflation.

Following Pesaran, Shin, and Smith (2001) we modified equation (15) to include the monetary variables. The dynamic equation called an autoregressive distributed lag (ARDL) of order $k$ as follows:

$$
\begin{aligned}
\Delta C P I_{t}= & \alpha_{0}+\sum_{t=i}^{n} \alpha_{1 i} \Delta C P I_{t-i}+\sum_{t=i}^{n} \alpha_{2 i} \Delta E X C R T_{t-i}+\sum_{t=i}^{n} \alpha_{3 i} \Delta I N T R T_{t-i}+\sum_{t=i}^{n} \alpha_{4 i} \Delta M 2_{t-i} \\
& +\beta_{1} C P I_{t-1}+\beta_{2} E X C R T_{t-1}+\beta_{3} I N T R T_{t-1}+\beta_{4} M 2_{t-1}+\varepsilon_{t}
\end{aligned}
$$

where $\Delta$ denotes the first difference, $\alpha_{0}$ is the drift component, and $\varepsilon_{\mathrm{t}}$ is the usual white noise residual.

The left-hand side is the inflation (CPI). The first until fourth expressions $\left(\alpha_{1}-\alpha_{4}\right)$ on the right-hand side correspond to the short-run dynamics of the model. The remaining expressions with the $\left(\beta_{1}-\beta_{4}\right)$ represent the long-run dynamics of the model.

A priori expectations of the coefficients of the variables

$$
\alpha_{1}>0, \alpha_{2}>0, \alpha_{3}<0, \alpha_{4}>0 \text {. }
$$

The $a$ priori expressions above imply that higher inflation expectation, resulting from higher inflation in the previous period, could induce money demand and consequently increase prices. A depreciation of the exchange rate is expected to fuel inflation by increasing import prices. Interest rate is expected to be negatively related to inflation because a higher rate of return is expected to be associated with a decrease in money holding, reducing inflation. In other words, a higher return on assets makes them more attractive than money. An increase in money supply is expected to increase inflation.

\section{The ARIMA Model Specification}

The Box-Jenkins (ARIMA) econometric modelling takes into account historical data and decomposes it into Autoregressive (AR) process, where there is a memory of past events; an Integrated (I) process, which accounts for stabilizing or making the data stationary, making it easier to forecast; and a Moving Average (MA) of the forecast errors, such that the longer the historical data, the more accurate the forecasts will be, as it learns over time. ARIMA models therefore have three model parameters, one for the AR $(p)$ process, one for the I $(d)$ process, and one for the $\operatorname{MA}(q)$ process, all combined and interacting among each other and recomposed into the ARIMA $(p, d, q)$ model. The ARIMA models are applicable only to a stationary data series, where the mean, the variance, and the autocorrelation function remain constant through time. The only kind of nonstationarity supported by ARIMA model is simple differencing of degree $d$. In practice, one or two levels of differencing are often enough to reduce a nonstationary time series to apparent stationarity (Makridakis, Wheelwright, \& Hyndman, 1998; Pindyck \& Rubinfeld, 1981).

A pth-order autoregressive process expresses a dependent variable as a function of past values of the dependent variable, as in:

$$
Y_{t}=\phi_{0}+\phi_{1} Y_{t-1}+\phi_{2} Y_{t-2}+\cdots+\phi_{p} Y_{t-p}+\varepsilon_{t}
$$


INTERNATIONAL JOURNAL OF ACADEMIC RESEARCH IN BUSINESS AND SOCIAL SCIENCES

Vol. 10, No. 2, Feb, 2020, E-ISSN: 2222-6990 @ 2020 HRMARS

where

$Y_{t}$ is the response (dependent) variable being forecasted at time $t$.

$Y_{t-1}, Y_{t-2}, \cdots, Y_{t-p}$ is the response variable at time lags.

$\phi_{1}, \phi_{2}, \cdots, \phi_{p}$ are the coefficients to be estimated.

$\varepsilon_{t}$ is the error term at time $t$.

A qth-order moving-average process expresses a dependent variable $Y_{t}$ as a function of the past values of the $q$ error terms, as in:

$$
Y_{t}=\mu+\varepsilon_{t}+\theta_{1} \varepsilon_{t-1}+\theta_{2} \varepsilon_{t-2}+\cdots+\theta_{q} \varepsilon_{t-q}
$$

Where:

$Y_{t}$ is the response (dependent) variable being forecasted at time $t$.

$\mu$ is the constant mean of the process.

$\theta_{1}, \theta_{2}, \cdots, \theta_{p}$ are the coefficients to be estimated.

$\varepsilon_{t}$ is the error term at time $t$.

$\varepsilon_{t-1}, \varepsilon_{t-2}, \ldots, \varepsilon_{t-q}$ are the errors in previous time periods that are incorporated in the in the response $Y_{t}$.

Such a function is a moving average of past error terms that can be added to the mean of $Y$ to obtain a moving average of past values of $Y$. Such an equation would be a "qth-order" moving-average process.

To create an ARIMA model, we began with an econometric equation with no independent variables $\left(Y_{t}=\beta_{0}+\varepsilon_{t}\right)$ and added to it both the autoregressive (AR) process and the moving-average (MA) process.

$$
Y_{t}=\beta_{0}+\phi_{1} Y_{t-1}+\phi_{2} Y_{t-2}+\cdots+\phi_{p} Y_{t-p}+\varepsilon_{t}+\theta_{1} \varepsilon_{t-1}+\theta_{2} \varepsilon_{t-2}+\cdots+\theta_{q} \varepsilon_{t-q}
$$

where the $\phi \mathrm{s}$ and $\theta$ s are the coefficients of the autoregressive and moving-average processes, respectively.

Following Box and Jenkins (1976), an autoregressive moving average (ARIMA) model may be specified as thus:

$$
C P I_{t}=\beta_{0}+\phi_{1} C P I_{t-1}+\phi_{2} C P I_{t-2}+\cdots+\phi_{p} C P I_{t-p}+\varepsilon_{t}+\theta_{1} \varepsilon_{t-1}+\theta_{2} \varepsilon_{t-2}+\cdots+\theta_{q} \varepsilon_{t-q}
$$

where $C P I_{t}$ is the inflation series and $\beta_{0}, \phi$, and $\theta$ are the parameters to be estimated.

Before this equation can be applied to a time series, however, it must be assumed that series is stationary. A nonstationary series can often be converted into a stationary one by taking the first difference of the variable in question.

$$
C P I_{t}^{*}=\Delta C P I_{t}=C P I_{t}-C P I_{t-1}
$$

If the first difference does not produce a stationary series then first difference of this firstdifferenced series can be taken. The resulting series is a second-difference transformation:

$$
C P I_{t}^{* *}=\left(\triangle C P I_{t}^{*}\right)=C P I_{t}^{*}-C P I_{t-1}^{*}=\Delta C P I_{t}-\Delta C P I_{t-1}
$$


INTERNATIONAL JOURNAL OF ACADEMIC RESEARCH IN BUSINESS AND SOCIAL SCIENCES Vol. 10, No. 2, Feb, 2020, E-ISSN: 2222-6990 @ 2020 HRMARS

The dependent variable in Equation 23 must be stationary, so the $C P I$ in that equation may be $C P I, C P I^{*}$, or even $C P I^{* *}$, depending on the variable in question. If a forecast of $C P I^{*}$ or $C P I^{* *}$ is made, then it must be converted back into $C P I$ terms before its use; for example, if $d=1$, then

$$
C P \hat{I}_{T+1}=C P I_{T}+C P \hat{I}_{T+1}^{*}
$$

If the original series is stationary and $d$ therefore equals 0 , this is shortened to ARMA. As a shorthand, an ARIMA model with $p, d$, and $q$ specified is usually denoted as $\operatorname{ARIMA}(p, d, q)$ with the specific integers chosen inserted for $p, d$, and $q$, as in $\operatorname{ARIMA}(2,1,1)$. ARIMA $(2,1,1)$ would indicate a model with two autoregressive terms, one difference, and one moving average term:

$$
\operatorname{ARIMA}(2,1,1): Y_{t}^{*}=\beta_{0}+\theta_{1} Y_{t-1}^{*}+\theta_{2} Y_{t-2}^{*}+\varepsilon_{t}+\phi_{1} \varepsilon_{t-1}
$$

Forecasts are often more useful if they are accompanied by a confidence interval, which is a range within which the actual value of the dependent variable is expected to lie. This is given as:

$$
C P \hat{I}_{T+1} \pm S_{F} t_{c}
$$

where $S_{F}$ is the estimated standard error of the forecast and $t_{c}$ is the critical two-tailed $t$-value for the desired level of significance.

\section{Estimation Procedure}

The analyses were carried out in four phases. The first phase was some pre-test analysis to ascertain the stationarity in the Nigerian variables selected for the models. The second phase proceeded to the estimation of the selected ARDL model ARIMA model. The third phase provided some post-estimation analyses (diagnostics testing of the models). The fourth phase assessed the forecasting performance of the models using forecasting measures such as root mean square error (RMSE) and absolute error (MAE).

\section{Empirical Analysis}

\section{Empirical Analysis and Results}

The first step in modelling a series is to check the structure of the data in order to obtain some preliminary knowledge about the stationarity of the series. The Augmented Dickey-Fuller (ADF) unit root test results for the time series variables are presented in Table 1 below.

Table 1: Augmented Dickey-Fuller Test (Null Hypothesis: Has a Unit Root)

\begin{tabular}{|c|c|c|l|}
\hline Variable & $\begin{array}{c}\text { ADF } \\
\text { Test Statistic }\end{array}$ & $\begin{array}{c}\text { 95\% Critical } \\
\text { ADF Value }\end{array}$ & \multicolumn{1}{|c|}{ Remark } \\
\hline $\mathrm{D}(\mathrm{CPI})$ & -13.321 & -2.887 & Stationary \\
\hline $\mathrm{D}(\mathrm{EXRT})$ & -9.397 & -2.887 & Stationary \\
\hline $\mathrm{D}(\mathrm{INTR})$ & -10.322 & -2.887 & Stationary \\
\hline $\mathrm{D}(\mathrm{M} 2)$ & -10.753 & -2.887 & Stationary \\
\hline
\end{tabular}

\section{Source: Authors' Calculations.}

The ADF results show all the variables became stationary after their first difference. Thus, we accept the hypothesis of unit roots in each of the time series. 
INTERNATIONAL JOURNAL OF ACADEMIC RESEARCH IN BUSINESS AND SOCIAL SCIENCES

Vol. 10, No. 2, Feb, 2020, E-ISSN: 2222-6990 @ 2020 HRMARS

\section{Co-Integration Analysis}

The Engel and Granger two-stage co-integration test result for the research model is presented in Table 2 below.

Table 2: Engel and Granger Residual Based Co-Integration Test

\begin{tabular}{|c|c|c|c|l|}
\hline SERIES & ADF & 5\% CRITICAL VALUE & $\begin{array}{l}\text { ORDER OF } \\
\text { INTEGRATION }\end{array}$ & REMARK \\
\hline RESIDUAL & -3.22 & -2.886 & $I(0)$ & Co-integrated \\
\hline
\end{tabular}

Source: Authors' Calculations.

The results in Table 2 show that there is co-integration among inflation (CPI), exchange rate (EXRT), interest rate (INTR), and broad money supply (M2). This means that any short-run deviation in their relationships would return to equilibrium in the long-run.

\section{Autoregressive Distributed Lag (ARDL) Model Estimation}

In order to examine the long-run and short-run relationships between inflation and its focus variables, an ARDL model (Pesaran, Shin, \& Smith, 2001) with four lags was estimated. Following Hendry's (1995) general to specific modelling approach, the result of the model is reported in Table 3 below.

Table 3: The Parsimonious ARDL (4, 2, 2, 1) Result

Dependent Variable: D(CPI)

Method: Least Squares

\begin{tabular}{ccccc}
\hline \hline Variable & Coefficient & Std. Error & t-Statistic & Prob. \\
\hline \hline C & -0.775865 & 0.958668 & -0.809316 & 0.4204 \\
ARDL Short Run Coefficient Estimates & & \\
D(CPI(-4)) & 0.473322 & 0.091408 & 5.178106 & 0.0000 \\
D(EXRT(-2)) & -0.073866 & 0.037195 & -1.985889 & 0.0501 \\
D(INTR(-2)) & -0.224231 & 0.131201 & -1.709073 & 0.0908 \\
D(M2) & $1.59 \mathrm{E}-06$ & $8.49 \mathrm{E}-07$ & 1.866825 & 0.0651 \\
D(M2(-1)) & $1.86 \mathrm{E}-06$ & $7.87 \mathrm{E}-07$ & 2.360932 & 0.0204 \\
ARDL Long Run Coefficient Estimates & & \\
CPI(-1) & -0.038096 & 0.020475 & -1.860558 & 0.0660 \\
EXRT(-1) & 0.034787 & 0.014649 & 2.374735 & 0.0197 \\
INTR(-1) & 0.101592 & 0.054950 & 1.848825 & 0.0677 \\
M2(-1) & $5.92 \mathrm{E}-07$ & $3.12 \mathrm{E}-07$ & 1.896062 & 0.0611 \\
\hline \hline
\end{tabular}

Source: Authors' Calculations. 
INTERNATIONAL JOURNAL OF ACADEMIC RESEARCH IN BUSINESS AND SOCIAL SCIENCES Vol. 10, No. 2, Feb, 2020, E-ISSN: 2222-6990 @ 2020 HRMARS

The parsimonious model equation can be formed as:

$$
\begin{aligned}
& D(C P I)=-0.776+0.473 \Delta C P I_{t-4}-0.074 \Delta E X R T_{t-2}-0.224 \Delta I N T R T_{t-2}+1.59 \Delta L M 2_{t}+1.86 \Delta L M 2_{t-1} \\
& \begin{array}{cccc}
(-0.420)(5.18) & (-1.99) & (-1.71) & (1.87) \\
-0.038 C P I_{t-1} & +0.034 E X R T_{t-1}+0.101 I N T R T_{t-1}+5.92 E^{-07} L M 2_{t-1} \\
(-1.86) & (2.37) & (1.85)
\end{array}
\end{aligned}
$$

\section{ARIMA Model Identification, Selection, Estimation}

ARIMA models are univariate models that consist of an autoregressive polynomial, an order of integration $(d)$, and a moving average polynomial. We have to identify the model, estimate suitable parameters, perform diagnostics for residuals, and finally forecast the inflation series.

\section{ARIMA Model Identification}

Firstly, we computed the series correlogram which consists of ACF and PACF values as in Figure 1. We observed the patterns of the ACF and PACF, and then determine the parameter values $p$ and $q$ for ARIMA model. The correlogram for ACF and PACF of the second order difference series was plotted in Figure 1.

\begin{tabular}{|c|c|c|c|c|c|c|}
\hline Autocorrelation & Partial Correlation & & $A C$ & PAC & Q-Stat & Prob \\
\hline. $\mid * * * * * * *$ &. $\mid * * * * * * *$ & 1 & 0.971 & 0.971 & 116.03 & 0.000 \\
\hline. $\mid * * * * * * *$ & $.1 . \quad 1$ & 2 & 0.942 & -0.012 & 226.22 & 0.000 \\
\hline. $\mid * * * * * * *$ &.$|. \quad|$ & 3 & 0.914 & -0.008 & 330.77 & 0.000 \\
\hline.$|* * * * * *|$ & $.1 . \quad \mid$ & 4 & 0.886 & -0.009 & 429.87 & 0.000 \\
\hline.$|* * * * * *|$ & $.1 . \quad \mid$ & 5 & 0.856 & -0.053 & 523.14 & 0.000 \\
\hline.$|* * * * * *|$ & $.1 . \quad \mid$ & 6 & 0.826 & -0.022 & 610.66 & 0.000 \\
\hline.$|* * * * * *|$ & $.1 . \quad 1$ & 7 & 0.797 & 0.012 & 692.91 & 0.000 \\
\hline.$|* * * * * *|$ &.$|. \quad|$ & 8 & 0.769 & 0.008 & 770.29 & 0.000 \\
\hline$.||^{* * * *} \mid$ &.$|. \quad|$ & 9 & 0.742 & -0.022 & 842.82 & 0.000 \\
\hline$.||^{* * * * *} \mid$ & $.1 . \quad \mid$ & 10 & 0.713 & -0.034 & 910.41 & 0.000 \\
\hline.$|* * * * *|$ &.$|. \quad|$ & 11 & 0.686 & 0.018 & 973.58 & 0.000 \\
\hline.$|* * * * *|$ &.$|. \quad|$ & 12 & 0.662 & 0.028 & 1032.9 & 0.000 \\
\hline.$|* * * * *|$ &.$|. \quad|$ & 13 & 0.637 & -0.015 & 1088.5 & 0.000 \\
\hline$.||^{* * * *} \mid$ &.$|. \quad|$ & 14 & 0.611 & -0.045 & 1140.1 & 0.000 \\
\hline$.||^{* * * *} \mid$ &.$|. \quad|$ & 15 & 0.586 & 0.003 & 1188.0 & 0.000 \\
\hline.$|* * * *|$ &.$|. \quad|$ & 16 & 0.562 & -0.008 & 1232.4 & 0.000 \\
\hline$.||^{* * * *} \mid$ &.$|. \quad|$ & 17 & 0.537 & -0.025 & 1273.4 & 0.000 \\
\hline$.||^{* * * *} \mid$ &.$|. \quad|$ & 18 & 0.509 & -0.059 & 1310.6 & 0.000 \\
\hline$.\left.\right|^{* * * *} \mid$ & $.1 . \quad 1$ & 19 & 0.484 & 0.019 & 1344.5 & 0.000 \\
\hline$.\left.\right|^{* * *} \quad \mid$ &.$|. \quad|$ & 20 & 0.458 & -0.020 & 1375.3 & 0.000 \\
\hline$.||^{* * *} \mid$ &.$|. \quad|$ & 21 & 0.433 & -0.007 & 1403.1 & 0.000 \\
\hline$.\left.\right|^{* * *} \mid$ & $*|. \quad|$ & 22 & 0.405 & -0.071 & 1427.6 & 0.000 \\
\hline
\end{tabular}

\section{CORRELOGRAM OF D(CPI) RESIDUALS}


INTERNATIONAL JOURNAL OF ACADEMIC RESEARCH IN BUSINESS AND SOCIAL SCIENCES Vol. 10, No. 2, Feb, 2020, E-ISSN: 2222-6990 @ 2020 HRMARS

\begin{tabular}{|c|c|c|c|c|c|}
\hline.$\left.\right|^{* * *}$ &.$|. \quad|$ & 23 & 0.3800 .033 & 1449.3 & 0.000 \\
\hline.$\left.\right|^{* * *}$ & $.1 . \quad 1$ & 24 & 0.3560 .001 & 1468.6 & 0.000 \\
\hline$.\left.\right|^{* *} \quad \mid$ & .1 & 25 & $0.332-0.012$ & 1485.6 & 0.000 \\
\hline$\left.\right|^{* *}$ & .1 & 26 & 0.3090 .005 & 1500.5 & 0.000 \\
\hline$\left.\right|^{* *}$ & .1 & 27 & $0.287-0.003$ & 1513.5 & 0.000 \\
\hline$\left.\right|^{* *}$ & .1 & 28 & $0.266-0.017$ & 1524.8 & 0.000 \\
\hline$\left.\right|^{* *}$ &.$l$. & 29 & $0.243-0.045$ & 1534.3 & 0.000 \\
\hline.$^{* *}$ & .1 & 30 & $0.221-0.006$ & 1542.2 & 0.000 \\
\hline$.\left.\right|^{*} \quad \mid$ & .1 & 31 & $0.200 \quad 0.023$ & 1548.8 & 0.000 \\
\hline.$^{*}$ &.$l$ & 32 & 0.1830 .020 & 1554.3 & 0.000 \\
\hline.$^{*}$ & .1 & 33 & $0.164-0.029$ & 1558.9 & 0.000 \\
\hline.$^{*}$ & .1. & 34 & $0.144-0.028$ & 1562.4 & 0.000 \\
\hline.$^{*}$ & .1 & 35 & $0.125-0.003$ & 1565.1 & 0.000 \\
\hline.$^{*}$ & $.1 . \quad \mid$ & 36 & $0.107-0.021$ & 1567.1 & 0.000 \\
\hline
\end{tabular}

Figure 1: Correlogram of the second order difference CPI series Source: Authors' Calculations.

In Figure 1, 36 lags of autocorrelation and partial autocorrelation were generated. The ACF died out after lag 2(AR) and PACF died out slowly after lag 4(MA). Thus, the $p$ and $q$ values for the $\operatorname{ARIMA}(p, 1, q)$ model were set at 2 and 4 respectively. From the correlogram of the first-order differenced series, the AIC and SIC criteria were used to select the most desirable ARIMA model. The results of all the ARIMA combinations are presented in Table 4. 
INTERNATIONAL JOURNAL OF ACADEMIC RESEARCH IN BUSINESS AND SOCIAL SCIENCES

Vol. 10, No. 2, Feb, 2020, E-ISSN: 2222-6990 @ 2020 HRMARS

Table 4: ARIMA Models for Forecasting Inflation

\begin{tabular}{|c|c|c|c|c|c|c|c|c|}
\hline Variable & $\begin{array}{c}\text { ARIMA } \\
(1,1,1)\end{array}$ & $\begin{array}{c}\text { ARIMA } \\
(1,1,2)\end{array}$ & $\begin{array}{c}\text { ARIMA } \\
(1,1,3)\end{array}$ & $\begin{array}{r}\text { ARIMA } \\
(1,1,4)\end{array}$ & $\begin{array}{c}\text { ARIMA } \\
(2,1,1)\end{array}$ & $\begin{array}{c}\text { ARIMA } \\
(2,1,2)\end{array}$ & $\begin{array}{c}\text { ARIMA } \\
(2,1,3)\end{array}$ & $\begin{array}{c}\text { ARIMA } \\
(2,1,4)\end{array}$ \\
\hline$C$ & $\begin{array}{r}-0.0003 \\
(0.005)\end{array}$ & $\begin{array}{c}-0.0004 \\
(0.00)\end{array}$ & $\begin{array}{c}-0.0004 \\
(0.0023 \\
)\end{array}$ & $\begin{array}{c}-0.0002 \\
(0.69)\end{array}$ & $\begin{array}{l}-0.000 \\
(0.99)\end{array}$ & $\begin{array}{c}-0.000 \\
(0.98)\end{array}$ & $\begin{array}{l}0.000 \\
(0.94)\end{array}$ & $\begin{array}{l}-0.000 \\
(0.98)\end{array}$ \\
\hline$A R(1)$ & $\begin{array}{c}0.35 \\
(0.000) \\
\end{array}$ & $\begin{array}{c}0.03 \\
(0.90) \\
\end{array}$ & $\begin{array}{c}-0.32 \\
(0.66) \\
\end{array}$ & $\begin{array}{l}-0.35 \\
(0.45) \\
\end{array}$ & $\begin{array}{l}0.003 \\
(0.99) \\
\end{array}$ & $\begin{array}{c}0.17 \\
(0.31) \\
\end{array}$ & $\begin{array}{c}-0.005 \\
(0.67) \\
\end{array}$ & $\begin{array}{l}-0.005 \\
(0.70) \\
\end{array}$ \\
\hline$A R(2)$ & & & & & $\begin{array}{c}-3.89 \\
(0.0002)\end{array}$ & $\begin{array}{l}-0.606 \\
(0.000)\end{array}$ & $\begin{array}{c}-0.97 \\
(0.000)\end{array}$ & $\begin{array}{c}-0.97 \\
(0.000)\end{array}$ \\
\hline $\mathrm{MA}(1)$ & $\begin{array}{c}-0.99 \\
(0.000)\end{array}$ & $\begin{array}{c}-0.63 \\
(0.006)\end{array}$ & $\begin{array}{l}-0.24 \\
(0.74)\end{array}$ & $\begin{array}{l}-0.19 \\
(0.68)\end{array}$ & $\begin{array}{c}-0.55 \\
(0.000)\end{array}$ & $\begin{array}{c}-0.70 \\
(0.0004 \\
)\end{array}$ & $\begin{array}{c}-0.62 \\
(0.000)\end{array}$ & $\begin{array}{c}-0.58 \\
(0.000)\end{array}$ \\
\hline$M A(2)$ & & $\begin{array}{l}-0.36 \\
(0.11) \\
\end{array}$ & $\begin{array}{c}-0.52 \\
(0.26) \\
\end{array}$ & $\begin{array}{c}-0.55 \\
(0.027) \\
\end{array}$ & & $\begin{array}{c}0.36 \\
(0.033) \\
\end{array}$ & $\begin{array}{c}0.96 \\
(0.000) \\
\end{array}$ & $\begin{array}{c}0.79 \\
(0.000) \\
\end{array}$ \\
\hline$M A(3)$ & & & $\begin{array}{c}-0.23 \\
(0.399)\end{array}$ & $\begin{array}{c}-0.27 \\
(0.08)\end{array}$ & & & $\begin{array}{c}-0.69 \\
(0.000)\end{array}$ & $\begin{array}{c}-0.65 \\
(0.000)\end{array}$ \\
\hline $\mathrm{MA}(4)$ & & & & $\begin{array}{c}0.14 \\
(0.22)\end{array}$ & & & & $\begin{array}{c}-0.17 \\
(0.083)\end{array}$ \\
\hline$R^{2}$ & 0.33 & 0.34 & 0.35 & 0.35 & 0.35 & 0.37 & 0.48 & 0.48 \\
\hline$A j R^{2}$ & 0.32 & 0.32 & 0.32 & 0.32 & 0.33 & 0.35 & 0.45 & 0.46 \\
\hline DW & 1.93 & 1.99 & 2.05 & 2.02 & 2.07 & 2.08 & 1.86 & 1.97 \\
\hline $\mathrm{AIC}$ & -2.87 & -2.87 & -2.87 & -2.86 & -2.88 & -2.90 & -3.06 & -3.06 \\
\hline SIC & -2.80 & -2.78 & -2.75 & -2.71 & -2.79 & -2.78 & -2.92 & -2.90 \\
\hline JB & & & & & & & & \\
\hline RMSE & 0.069 & 0.068 & 0.068 & 0.068 & 0.068 & 0.068 & 0.059 & 0.059 \\
\hline MAE & & & & & & & & \\
\hline MAPE & 99.5 & 97.6 & 99.9 & 104.4 & 118 & 140 & 598 & 597 \\
\hline TIC & .98 & 0.98 & 0.98 & 0.99 & 0.96 & 0.96 & 0.57 & 0.58 \\
\hline
\end{tabular}

Source: Authors' Calculations.

In selecting the best ARIMA model of inflation we subjected all the ARIMA models to Akaike Information Criterion (AIC) and Schwarz Information Criterion (SIC). The results are shown in Table 5.

Table 5: ARIMA Model Selection

\begin{tabular}{|l|l|l|}
\hline ARIMA TYPE & AIC & SIC \\
\hline ARIMA $(1,1,1)$ & -2.87 & -2.80 \\
\hline ARIMA $(1,1,2)$ & -2.87 & -2.78 \\
\hline ARIMA $(1,1,3)$ & -2.87 & -2.75 \\
\hline ARIMA $(1,1,4)$ & -2.86 & -2.71 \\
\hline ARIMA $(2,1,1)$ & -2.88 & -2.79 \\
\hline ARIMA $(2,1,2)$ & -2.90 & -2.78 \\
\hline ARIMA(2,1,3) & $-3.06^{*}$ & $-2.92^{*}$ \\
\hline ARIMA(2,1,4) & -3.06 & -2.90 \\
\hline
\end{tabular}

Source: Authors' Calculations 
INTERNATIONAL JOURNAL OF ACADEMIC RESEARCH IN BUSINESS AND SOCIAL SCIENCES Vol. 10, No. 2, Feb, 2020, E-ISSN: 2222-6990 ¿ 2020 HRMARS

The results in Table 5 show that $\operatorname{ARIMA}(2,1,3)$ is preferred to others since it has the lowest values of AIC and SBC.

\section{$\operatorname{ARIMA}(2,1,3)$ Estimation}

When we have identified the ARIMA model, the next step was to estimate the parametric coefficients. The parameter estimation of the model was conducted using the EViews software. Table 6 presents the results.

Table 6: ARIMA $(2,1,3)$ Result

Dependent Variable: D(CPI)

\begin{tabular}{ccccc}
\hline \hline Variable & Coefficient & Std. Error & t-Statistic & Prob. \\
\hline \hline C & -29.22521 & 17.13782 & -1.705305 & 0.0909 \\
AR(1) & 0.521563 & 0.183685 & 2.839444 & 0.0054 \\
AR(2) & 0.509840 & 0.187250 & 2.722780 & 0.0075 \\
MA(1) & 0.588749 & 0.178505 & 3.298220 & 0.0013 \\
MA(2) & -0.006624 & 0.110930 & -0.059717 & 0.9525 \\
MA(3) & -0.362992 & 0.095313 & -3.808403 & 0.0002 \\
\hline \hline R-squared & 0.48 & & & \\
Adjusted R-squared & 0.45 & & & \\
F-statistic & 14295.93 & & & \\
Prob(F-statistic) & 0.00 & & & \\
lnverted AR Roots & 1.02 & -.50 & & \\
Inverted MA Roots & .56 & $-.58+.56 i$ & $-.58-.56 i$ & \\
\hline \hline
\end{tabular}

Source: Authors' Calculations.

$$
\begin{aligned}
& \Delta(C P I)_{t}=-29.23+0.52 \Delta C P I_{t-1}+0.51 \Delta C P I_{t-2}-0.59 \varepsilon_{t-1}+0.007 \varepsilon_{t-2}-0.36 \varepsilon_{t-3} \\
& \begin{array}{lllll}
(-29.2) & (2.87) & (2.72) & (3.30) & (-0.06)
\end{array} \quad(-3.81)
\end{aligned}
$$

\section{$\operatorname{ARDL}(4,2,2,1)$ and $\operatorname{ARIMA}(2,1,3)$ Models Diagnostics}

The estimated ARDL (4, 2, 2, 1) model and ARIMA (2, 1, 3) model were tested for autocorrelation (Breusch-Godfrey serial correlation LM test), normality (Jarque-Bera test), and specification error (Ramsey RESET test). The results are shown in Table 7. 
INTERNATIONAL JOURNAL OF ACADEMIC RESEARCH IN BUSINESS AND SOCIAL SCIENCES Vol. 10, No. 2, Feb, 2020, E-ISSN: 2222-6990 @ 2020 HRMARS

Table 7: ARDL $(4,2,2,1)$ and ARIMA $(2,1,3)$ Models Diagnostics

\begin{tabular}{|l|c|c|}
\hline TEST & ARDL (4, 2, 2, 1) & $\begin{array}{l}\text { ARIMA (2, 1, } \\
\text { 3) }\end{array}$ \\
\hline Stability: Ramsey RESET test & 1.00 & 0.883 \\
& $(0.32)$ & $(0.42)$ \\
\hline Serial correlation: & 4.23 & 1.468 \\
Breusch-Godfrey LM test & $(0.22)$ & $(0.24)$ \\
\hline Normality: Jarque-Bera test & 232.73 & 25.01 \\
& $(0.00)$ & $(0.00)$ \\
\hline
\end{tabular}

Source: Authors' Calculations

The results in Table 7 suggest that the models were well specified on the basis of Ramsey RESET test and serially uncorrelated on the basis of Breusch-Godfrey serial correlation LM test. The Jarque-Bera (JB) tests for the residuals indicate that the residuals from both ARDL $(4,2,2,1)$ and $\operatorname{ARIMA}(2,1,3)$ models are normally distributed at $1 \%$. This means that the models are valid and can be used for policy recommendations without re-specification.

\section{Interpretation of $\operatorname{ARDL}(4,2,2,1)$ and $\operatorname{ARIMA}(2,1,3)$ Models}

Table 3 presents the results of short-run and long-run coefficients of the ARDL $(\mathbf{4}, \mathbf{2}, \mathbf{2}, \mathbf{1})$. The coefficient of determination $(R$-squared $=0.53$ ) of the estimated model shows that about $53 \%$ of the variation in inflation dynamics in Nigeria is jointly explained and accounted for by the independent variables in the estimated ARDL $(\mathbf{4}, \mathbf{2}, \mathbf{2}, \mathbf{1})$ model. This when adjusted for degree of freedom based on the adjusted coefficient of determination (Adjusted $R$-bar squared $=0.41$ ) shows that the ARDL $(4,2,2,1)$ model has about $41 \%$ predictive power with respect to dynamics of inflation in Nigeria. The $F$-test which is used to determine the overall statistical significance of a regression model shows that the overall regression is statistically significant at $1 \%$ level ( $F$-value $=4.50$. and $p$-value $=0.00$ ). This therefore means that the overall $\operatorname{ARDL}(\mathbf{4}, \mathbf{2}, \mathbf{2}, \mathbf{1})$ model is statistically different from zero.

As shown in Table 3, the fourth quarter lag of inflation (positive), the second quarter lag of exchange rate (negative), the second quarter lag of interest (negative), the current level of money supply (positive), and the first quarter lag of money supply (positive) were statistically significant in influencing inflation dynamics in Nigeria in the short run. In the long-run, expected inflation (negative), exchange rate (positive), interest rate (positive), and broad money supply (positive) were all statistically significant in influencing inflation dynamics in Nigeria. These findings are consistent with the findings of Adenekan and Nwanna (2004) (past inflation), Olubusoye and Oyaromade (2009) (money stock, expected inflation, interest, and exchange rates), and Rapu, Gaiya, Eborieme, Nkang, Audu, Golit, and Okafor (2016) (money supply, and exchange rate)

In Table 6, ARIMA $(2,1,3)$ results indicate that the coefficients of AR $(2)$ and MA $(3)$ were highly significant at $1 \%$ levels. The AIC (-3.06) and SIC (-2.92) were lower in values when compared to $\operatorname{ARIMA}(1,1,1), \operatorname{ARIMA}(1,1,2),(1,1,3),(1,1,4), \operatorname{ARIMA}(2,1,1), \operatorname{ARIMA}(2,1,2)$, and $\operatorname{ARIMA}(2,1,4)$. The coefficient of determination ( $R$-squared) is 0.48 which implies that that about $48 \%$ of the variation in inflation in Nigeria is explained past values of inflation and the past errors. This when adjusted for degree of freedom based on the adjusted coefficient of determination (Adjusted $R$-bar squared = 0.45 ) shows that the $\operatorname{ARIMA}(2,1,3)$ model has about $45 \%$ explanatory power with respect to dynamics of inflation in Nigeria. From the parsimonious ARIMA $(2,1,3)$ model, expected inflation was 
INTERNATIONAL JOURNAL OF ACADEMIC RESEARCH IN BUSINESS AND SOCIAL SCIENCES Vol. 10, No. 2, Feb, 2020, E-ISSN: 2222-6990 @ 2020 HRMARS

statistically significant in explaining Nigerian inflation dynamics. This is consistent with the results of Fakiyesi (1996), Adenekan and Nwanna (2004), and Olubusoye and Oyaromade (2009).

\section{Comparison of Performance of $\operatorname{ARDL}(4,2,2,1)$ and ARIMA $(2,1,3)$ Inflation Models}

Table 8 below provides information about the performance of the ARDL $(4,2,2,1)$ and ARIMA $(2,1,3)$ models used in this study.

Table 8: Performance of ARDL $(4,2,2,1)$ and ARIMA $(2,1,3)$ Models

\begin{tabular}{|l|c|c|}
\hline \multicolumn{1}{|c|}{ Performance } & ARDL $(4,2,2,1)$ & ARIMA $(2,1,3)$ \\
\hline$R$-squared $\left(R^{2}\right)$ & 0.53 & 0.48 \\
\hline Adjusted $R$-squared $\left(\bar{R}^{2}\right)$ & 0.41 & 0.45 \\
\hline F-statistic & $4.50(0.00)$ & $19.98(0.00)$ \\
\hline Serial correlation: & 4.23 & 1.468 \\
Breusch-Godfrey serial & $(0.22)$ & $(0.24)$ \\
correlation LM test & & \\
\hline Normality: Jarque-Bera & 232.73 & 25.01 \\
test & $(0.00)$ & $(0.00)$ \\
\hline Stability: Ramsey RESET & 1.00 & 0.883 \\
test & $(0.32)$ & $(0.42)$ \\
& & \\
\hline
\end{tabular}

The results in Table 8 show that the coefficients of determination ( $R$-squared) of the estimated models are $53 \%$ and $48 \%$ for $\operatorname{ARDL}(4,2,2,1)$ and $\operatorname{ARIMA}(2,1,3)$ respectively. The coefficient of determination indicates the explanatory power of a model. This means that ARDL (4, $2,2,1)$ model has a higher explanatory power than $\operatorname{ARIMA}(2,1,3)$ model during the sample period. The adjusted coefficients of determination (Adjusted $R$-bar squared) are $41 \%$ and $45 \%$ for ARDL (4, $\mathbf{2}, \mathbf{2}, \mathbf{1})$ and $\operatorname{ARIMA}(2,1,3)$ respectively. The adjusted coefficient of determination is used to compare the predictive ability of models. This shows that $\operatorname{ARIMA}(2,1,3)$ model has a higher explanatory power of dynamics of inflation in Nigeria than $\operatorname{ARDL}(\mathbf{4}, \mathbf{2}, \mathbf{2}, \mathbf{1})$ model. The $F$-test which is used to determine the overall statistical significance of a regression model shows that the overall regression of the ARDL $(4,2,2,1)$ and $\operatorname{ARIMA}(2,1,3)$ is statistically significant at $1 \%$ level.

The results in Table 8 suggest that the models were well specified on the basis of Ramsey RESET test and serially uncorrelated on the basis of Breusch-Godfrey serial correlation LM test. The Jarque-Bera (JB) test for the residuals indicates that the residuals from both ARDL $(4,2,2,1)$ and $\operatorname{ARIMA}(2,1,3)$ models are normally distributed at $1 \%$. This means that the models are valid and can be used for policy recommendations without re-specification. In other words, ARDL $(\mathbf{4}, \mathbf{2}, \mathbf{2}, \mathbf{1})$ and $\operatorname{ARIMA}(2,1,3)$ models can be applied in explaining inflation dynamics in Nigeria over the sample period.

\section{Conclusion and Recommendations}

It is generally accepted that keeping low and stable rates of inflation is the primary objective of the central banks. Economic agents, private and public alike monitor closely the evolution of prices in the economy, in order to make decisions that allow them to optimize the use of their resources. In this context, it is very important to model inflation. 
This study found that $\operatorname{ARDL}(\mathbf{4}, \mathbf{2}, \mathbf{2}, \mathbf{1})$ and $\operatorname{ARIMA}(2,1,3)$ models were the most appropriate models under model identification, selection, parameter estimation, and diagnostic checking. The two models were used to examine the inflation dynamics in Nigeria using quarterly time series data from 1988 to 2017. The performances of the two models showed that ARDL $(\mathbf{4}, \mathbf{2}, \mathbf{2}, \mathbf{1})$ and ARIMA $(2,1,3)$ models perform very well. In other words, the performance of the two models was not statistically different. Therefore, we concluded that $\operatorname{ARDL}(\mathbf{4}, \mathbf{2}, \mathbf{2}, \mathbf{1})$ and $\operatorname{ARIMA}(2, \mathbf{1}, 3)$ models can be applied in explaining inflation dynamics in Nigeria.

Based on the findings of this study, the following recommendations are made:

1. $\operatorname{ARDL}(4,2,2,1)$ and $\operatorname{ARIMA}(2,1,3)$ models can be applied in explaining inflation dynamics in Nigeria. It is recommended that a "one-model-fits-all" for inflation rate dynamics in Nigeria should be discouraged. There is no model that is designed to answer all questions. Different models answer question about different sectors and time horizon of policies and events, they complement one another.

2. ARDL $(4,2,2,1)$ and $\operatorname{ARIMA}(2,1,3)$ models showed that the adaptive expectation theory holds in Nigeria since past inflation helps to predict future inflation. It is recommended that the regulatory authorities should ensure a high degree of transparency in monetary policy making and implementation.

3. Expected inflation, exchange rate, interest rate, and liquidity exert significant influence on inflation. It is recommended that alternative models of inflation dynamics in Nigeria should consider past inflation, exchange rate, interest rate, and liquidity as potential explanatory variables. It is also recommended that efforts should be made by the regulatory authorities to control money supply and ensure exchange rate and interest stability, in order to stem inflationary tendencies.

\section{Contribution to Knowledge}

The study has contributed to knowledge in the following ways. Firstly, most of the previous studies carried out examined inflation dynamics by applying one model; this study contributes to by using a multivariate ARDL model and a univariate ARIMA to examine the behaviour of inflation in Nigeria. Secondly, majority of the previous studies employed the static ordinary least squares (OLS) regression techniques which do not capture the short-run and long-run impacts of the variables simultaneously; this study contributes to knowledge by employing the autoregressive distributed lag (ARDL) method to simultaneously analyze the short-run and long-run impacts of $b$ fiscal policy instruments on economic growth in Nigeria. Thirdly, theoretically, this study has contributed to knowledge by showing that applying one-model-fits-all approach for inflation dynamics in Nigeria would yield misleading and invalid policy prescriptions. 
INTERNATIONAL JOURNAL OF ACADEMIC RESEARCH IN BUSINESS AND SOCIAL SCIENCES

Vol. 10, No. 2, Feb, 2020, E-ISSN: 2222-6990 @ 2020 HRMARS

\section{References}

Adebiyi, M. A., Adenuga, A. O., Abeng, M. O., Omanukwe, P.N., \& Ononugbo, M.C. (2010). Inflation forecasting models for Nigeria. Central Bank of Nigeria Occasional Paper No. 36. Abuja: Research and Statistics Department.

Adenekan, A. T., \& Nwanna, G. A. (2004). Inflation dynamics in a developing economy: An error correction approach. African Review of Money Finance and Banking, 77-99.

Adenikinju, A., Busari, D., \& Olofin, S. (2009). Applied econometrics and macroeconometric modelling in Nigeria. Ibadan: Ibadan University Press.

Adeyeye, E.A., \& Fakiyesi, T.O. (1980). Productivity prices and incomes board and anti-inflationary policy in Nigeria. Proceedings of the 1980 Annual Conference of the Nigerian Economic Society, 309-320.

Asogu, J. O. (1991). An econometric analysis of the nature and causes of inflation in Nigeria. Central Bank of Nigeria Economic and Financial Review, 29 (3), 19-30.

Barro, R. J., \& Grilli, V. (1997). European macroeconomics. London: Macmillan.

Box, G.E.P., \& Jenkins, G.M. (1976). Time series analysis: forecasting and control. San Francisco: Holden-Day.

Dwivedi, D. N. (2008). Managerial economics (7th ed.). Delhi: Vikas Publishing House PVT Limited.

Egwaikhide, O. E., Chete, L. N., \& Falokun, G. O. (1994). Exchange rate, money supply and inflation in Nigeria: an empirical investigation. African Journal of Economic Policy, 101, 57-73.

El-Mefleh, M.A., \& Shotar, M. (2008). A contribution to the analysis of the economic growth of Qatar. Applied Econometrics and International Development Journal, 8 (1), 18-35.

Engle, R. F., \& Granger, C. W. J. (1987). Co-integration and error-correction: representation, estimating and testing. Econometrica, 55, 251-276.

Fakiyesi, O. M. (1996). Further empirical analysis of inflation in Nigeria. Central Bank of Nigeria Economic and Financial Review, 34 (1), 489-499.

Friedman, B. M., \& Kuttner, K. N. (1993). Another look at the evidence on money-income causality. Journal of Econometrics, 57, 189-203.

Friedman, M., \& Schwartz, A. J. (1970). Monetary statistics in the U.S. estimates, sources, method. New York: National Bureau of Economic Research (NBER).

Hanke, J. E., \& Wichern, D. W. (2005). Business Forecasting (8th ed.). New York: Pearson Educational Incorporated.

Hendry, D. F. (1995). Dynamic econometrics. Oxford: Oxford University Press.

Katimon, A., \& Demun, A. S. (2004). Water use at Universiti Teknologi Malaysia: application of ARIMA model. Jurnal Teknologi, 41 (B), 47-56.

Makridakis, S., Wheelwright, S. C., \& Hyndman, R. J. (1998). Forecasting: methods and applications. New York: John Wiley \& Sons.

Moser, G. (1995). The main determinants of inflation in Nigeria. IMF Staff Papers 42.

Odedokun, M. O. (1993). An econometric analysis of inflation in sub-saharan Africa. Journal of African Economies, 4 (3), 436-51.

Olivera, J. H. G. (1964). On structural inflation and Latin American structuralism. Oxford Economic Papers, 16.

Olofin, S. (2001). An introduction to macroeconomics. Lagos: Malthouse Press Limited. 
INTERNATIONAL JOURNAL OF ACADEMIC RESEARCH IN BUSINESS AND SOCIAL SCIENCES

Vol. 10, No. 2, Feb, 2020, E-ISSN: 2222-6990 @ 2020 HRMARS

Olubusoye, E. O., \& Oyaromade, R. (2009). Modelling the dynamics of inflation in Nigeria. In Adenikinju, A., Busari, D., \& Olofin, S. (Eds.). Applied econometrics and macroeconometric modelling in Nigeria (pp. 161-194). Ibadan: Ibadan University Press.

Oyejide, T. A. (1972). Deficit financing and capital formation: An analysis of the Nigerian experience, 1957-1970, Nigerian Journal of Economic and Social Studies, 27-43.

Pesaran, M. H., Shin, Y., \& Smith, R. J. (2001). Bounds testing approaches to the analysis of level relationships. Journal of Applied Econometrics, 16, 289-326.

Pindyck, R., \& Rubinfiel, D. (1981). Econometric models and economic forecasts. Singapore: McGrawHill.

Rapu, S., Gaiya, B., Eborieme, M., Nkang, M., Audu, N., Golit, P., \& Okafor, H. (2016). A quantitative exploration of the drivers of inflation in Nigeria. Central Bank of Nigeria Economic and Financial Review, 54 (2), 2-21.

Roberts, F. S. (2006). Discrete mathematical models with application to social, biological and environmental problems. New York: Prentice Hall.

Samad, Q. A., Ali, M. Z., \& Hossain, M. Z. (2002). The forecasting performance of the Box-Jenkins Model: The case of wheat and wheat flour prices in Bangladesh. The Indian Journal of Economics, LXXXII (327), 509-518.

Stiglitz, J., \& Greenwald, B. (2003). Towards a new paradigm in monetary economics. Cambridge: Cambridge University Press.

Stockton, D., \&Glassman, J. (1987). An evaluation of the forecast performance of alternative models of inflation. Review of Economics and Statistics, 69 (1), 108-117.

Sunkel, O. (1960). Inflation in Chile: Unorthodox approach. Cited in Pahlavani, M. \& Rahimi, M. (2009). Sources of inflation in Iran: An application of the ARDL approach. International Journal of Applied Econometrics and Quantitative Studies, 2 (4), 46-62.

Valle, H. A. S. (2002). Inflation forecasts with ARIMA and vector autoregressive models in Guatemala. Economic Research Department, Guatemala: Banco de Guatemala. 